\title{
Development of mortar for laying and coating with pineapple fibers
}

\author{
Afonso R. Azevedo ${ }^{1,2}$, Markssuel T. Marvila ${ }^{1}$, Euzébio B. Zanelato ${ }^{1}$, Jonas Alexandre ${ }^{1}$, \\ Gustavo C. Xavier ${ }^{1} \&$ Daiane Cecchin ${ }^{2}$ \\ ${ }^{1}$ Universidade Estadual do Norte Fluminense Darcy Ribeiro/Laboratório de Engenharia Civil, Campos dos Goytacazes, RJ, Brasil. E-mail: \\ afonso.garcez91@gmail.com - ORCID: 0000-0002-4694-4459; markssuel@hotmail.com (Corresponding author) - ORCID: 0000-0002-2162-1872; \\ ebzanelato@gmail.com - ORCID: 0000-0002-3824-0195; jonas.uenf@gmail.com - ORCID: 0000-0002-2977-5585; gxavier@uenf.br - ORCID: \\ 0000-0002-4782-6577 \\ ${ }^{2}$ Universidade Federal Fluminense/Departamento de Engenharia Agrícola e Meio Ambiente, Niterói, RJ, Brasil. E-mail: daianececchin@id.uff.br - \\ ORCID: 0000-0002-6098-1846
}

\begin{abstract}
Brazil is one of the largest producers of pineapple in the world, which, in addition to bringing substantial benefits, contributes to increasing waste generation in the stages of processing, aiming at its consumption. The Brazilian environmental legislation has been increasingly more restrictive with respect to the disposal of solid waste, whether domestic, industrial or agro-industrial, which has stimulated studies related to the use of these materials in several matrices. This study aimed to evaluate the potentiality of using the natural fiber of pineapple (Ananas comosus), extracted from its leaves, as reinforcing material in cementitious composites. For this purpose, natural fiber extracted from the pineapple crown was incorporated in different percentages in relation to the cement mass: $0,2.5,5,7.5$ and $10 \%$, and the fibers obtained were submerged in aqueous $\mathrm{NaOH}$ solution with $5 \%$ concentration in volume, for $1 \mathrm{~h}$ at room temperature. The following variables were evaluated: consistency, water retention, incorporated air, mass density in hardened state, mechanical strength, water absorption by immersion and capillarity, besides verifying the influence of the mode of fiber incorporation. It was observed that the treatment with $\mathrm{NaOH}$ solution and the percentage of natural pineapple fiber incorporated in up to $5 \%$ in relation to the cement mass form mortars with technological feasibility.
\end{abstract}

Key words: Ananas comosus, agroindustrial residues, mixed mortars

\section{Desenvolvimento de argamassa para assentamento e revestimento com fibras de abacaxi}

RESUMO: O Brasil é um dos maiores produtores de abacaxi do mundo, o que além de trazer enormes benefícios contribui para o aumento da geração de resíduos nas etapas de beneficiamento, visando seu consumo. A legislação ambiental brasileira vem se tornando a cada ano mais restritiva quanto ao descarte dos resíduos sólidos, sejam domésticos, industriais ou agroindustriais, o que vem suscitando estudos relativos ao uso destes materiais em diversas matrizes. Esse trabalho visa avaliar a potencialidade da utilização da fibra natural do abacaxi, extraída da folha do abacaxizeiro (Ananás comosus) como material de reforço em compósitos cimentícios. Para este propósito, a fibra natural extraída da coroa do abacaxi foi incorporada em diferentes proporções em relação à massa de cimento: 0, 2,5, 5, 7,5 e 10\%, e as fibras obtidas foram submersas em solução aquosa de $\mathrm{NaOH}$ com concentração de $5 \%$ em volume, durante $1 \mathrm{~h}$ à temperatura ambiente. Foram avaliadas as seguintes variáveis: consistência, retenção de água, ar incorporado, densidade de massa no estado endurecido, resistência mecânica, absorção de água por imersão e por capilaridade, além de verificar a influência do modo de incorporação das fibras. Foi observado que o tratamento com solução de $\mathrm{NaOH}$ e a porcentagem de fibra natural de abacaxi incorporada em até $5 \%$ em relação à massa de cimento formam argamassas com viabilidade tecnológica.

Palavras-chave: Ananas comosus, resíduos agroindustriais, argamassas mistas

Editor responsible: Carlos Alberto Vieira de Azevedo 


\section{INTRODUCTION}

Pineapple is a symbol fruit of tropical and subtropical regions, with various beneficial properties for human health (Manetti, 2009). It belongs to the Bromeliaceae family, which has about 2700 species, distributed in 56 genera (Barros et al., 2017). Brazil stands out in the production of pineapple, being one of the largest producers and exporters in the world (Martinelli et al., 2019). As a comparison, the most recent data of IBGE (2017) highlight that the Brazilian production was equal to $1,502,598$ thousand pineapple fruits, in an area of 62,116 ha, which leads to a yield of 24,190 fruits ha $^{-1}$. It is worth pointing out that, according to Lima et al. (2017), 38\% of the pineapple fruit corresponds to residues, considering peel and crown.

The pineapple fruit is characterized by a cluster of one or two hundred small fruits around a central axis, in which each "eye" of the peel is a true fruit that grew from a flower, and these merge into a body, called multiple fruit, characterized as crown (Gil \& Maupoey, 2018).

One of the major problems arising from the processing of pineapple for consumption is extracting the crown, which leads to the generation of large amounts of residues, which can be reused as organic fertilizers or in the form of fibers for composites (Hazarika et al., 2017; Reddy et al., 2018).

The use of natural fibers as reinforcing material has aroused interest in several fields, such as civil engineering, mechanics, mechatronics and automobile industry (Rojas et al., 2018; Bencha et al., 2014), but the lack of normalized techniques is a problem in this reuse (Yusri et al., 2015).

Thus, this study aimed to evaluate the potentiality of using fiber from pineapple crown processing in mortars for laying and coating, evaluating all the way from its processing to the preparation of the cementitious composite concentration.

\section{Material AND Methods}

The study was conducted using Portland CPII-E-32 cement, $\mathrm{CH}-\mathrm{III}$ hydrated lime and natural river sand with $\mathrm{D}_{\mathrm{MAX}}=$ $2.40 \mathrm{~mm}$ in the preparation of the mortars for laying and coating. These materials were kept constant in all percentages evaluated and, therefore, did not interfere with the studied properties. The choice of these materials was based on their wide application in the civil construction sector (Marvila et al., 2019).

In addition, natural fiber extracted from the pineapple crown was incorporated in different percentages in relation to the cement mass: $0,2.5,5,7.5$ and $10 \%$. The fibers were obtained directly from the producers, since they remove them to sell the pineapples containing only the edible part of the fruit. The fibers were treated as follows: initially the material to be used was removed from the pineapple crown, and the other parts of the fruit structure were discarded. Then, the fiber was dried in an oven at temperature of $105^{\circ} \mathrm{C}$ for $48 \mathrm{~h}$, determined based on previously performed analyses (Marvila et al., 2019). After drying, the pineapple crowns were separated into branches and processed in a 3-L 1000-W Skymsen LB-220V industrial tilting blender, where they began to exhibit a fibrous form. This form of treatment originated fibers referred to as "natural", since no thermal or chemical treatment was performed to modify the variables that characterize these fibers. Figure 1 shows the aspect of the fibers studied during the stages of the treatment presented and detailed in this paragraph.

Another form of fiber treatment was also performed, following the methodology proposed by Motaleb et al. (2018), who studied the effect of the incorporation of pineapple fibers on the physical and mechanical properties of polymer composites. This treatment is considered more complex and follows the following detailed procedure: firstly, the material to be incorporated into the mortars, already properly extracted from the pineapple crown, was subjected to three processes of washing and drying, in order to remove any impurities present in its composition. After drying the material, pineapple crowns were separated into branches and processed in a $3-\mathrm{L} 1000-\mathrm{W}$ blender, the same device used in the previous procedure. After this process, the fibers obtained were submerged in aqueous $\mathrm{NaOH}$ solution with $5 \%$ concentration in volume, for $1 \mathrm{~h}$ at room temperature. This treatment is extremely important because it helps remove the hydrogen bond from the structure of the cellulose fiber network, thus increasing the surface roughness of the material. In addition, certain amounts of wax and oils covering the external surface of the cell wall of the fibers, such as lignin, are removed during this process (Motaleb et al., 2018). After the 1-h period, the samples were carefully washed until they reached neutral $\mathrm{pH}$ and subsequently dried in an oven again at temperature of $80^{\circ} \mathrm{C}$ for a period of $24 \mathrm{~h}$. The $\mathrm{pH}$ was measured using a Testo 206-pH2 $\mathrm{pH}$ meter, and the $\mathrm{NaOH}$ solution used was discarded in the local sewage network, with supervision of the Chemistry Laboratory of the University at which the research was conducted (LCQUIUENF), after $\mathrm{pH}$ neutralization, which is easily obtained by adding water to the solution, diluting the basic components. The fibers that received this form of treatment were referred to as "treated".

The fibers used in the study, which were obtained in the natural form and treated as explained in the previous paragraph, have the following characteristics: average diameter of 100-130 $\mu \mathrm{m}$ and average length of 10-20 mm.

The mortars prepared in this study have a 1:1:6 ratio among their constituents in volume (cement: hydrated lime: sand), and these percentages of the materials suggest an optimization of their technological parameters (Azevedo et al., 2018), besides being the most used in the Brazilian civil construction. Two different sets of mortars containing pineapple crown fiber were prepared: with incorporation of $2.5,5,7.5$ and $10 \%$ of

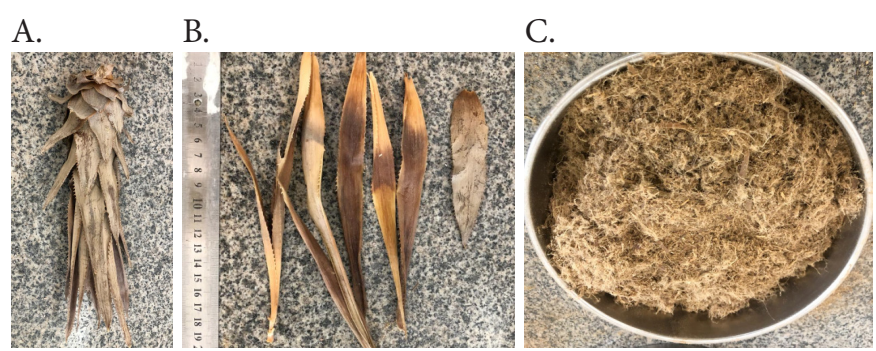

Figure 1. Fibers used: raw pineapple crown (A); separation of crown parts (B); fibers in their final form, before heat treatment $(\mathrm{C})$ 
natural fiber and with the same percentages, but with treated fibers. In addition, a reference without fiber incorporation was produced, referred to as $0 \%$. It should be pointed out that the same amounts of cement mass, hydrated lime and sand were used in all mortars. The studied fiber did not replace any component; the fiber percentages were added in relation to the cement mass (2.5 to $10 \%$ ).

The mortar mixing procedure followed the recommendations of the NBR 13276 norm (ABNT, 2016), in which the dry materials are all mixed and homogenized, including the fibers, and placed in a tub with the amount of water defined based on the consistency test. The mortar is then mixed for $90 \mathrm{~s}$ at low speed and left at rest for $15 \mathrm{~min}$, period that simulates the field condition in which the mortars are not applied shortly after their preparation due to the logistics of transport and handling.

The consistency test, following the NBR 13276 (ABNT, 2016), determines the consistency index of mortars, which is indicative of the workability of the material. The norm recommends a range of $260 \pm 5 \mathrm{~mm}$ on the flow table, a value used for the reference percentage of this study. The test consists in arbitrarily adding water to the reference percentage during its mixing stage. After the rest period has elapsed, the mortar is molded in a standardized conical frustum-shaped container with $12.5 \mathrm{~cm}$ of base diameter, $8 \mathrm{~cm}$ of top diameter and 6.5 $\mathrm{cm}$ of height, on a circular table with $50 \mathrm{~cm}$ in diameter. After molding, the conical mold is removed and the consistency table is lifted at a $14 \mathrm{~mm}$ height. The mortar then receives the impact caused by 30 successive falls in $30 \mathrm{~s}$ and spreads, forming a disc on the table. The diameter of this disc is measured in three different directions and the average value is the consistency index. More fluid mortars have higher consistency indices, while drier mortars spread less. The amount of water used for the reference percentage (0\%) to obtain the index of $260 \pm 5$ $\mathrm{mm}$ was the percentage of water defined for all mortars under study. The procedure was repeated for the other four percentages with incorporation of natural fiber and treated fiber, in order to verify the influence of fibers on the workability of the mortars.

Two other tests for mortars in the fresh state were conducted: the water retention test, following the procedures of NBR 13277 (ABNT, 2005a), and the incorporated air concentration, following the procedure of NBR 13278 (ABNT, 2005b). Both tests are extremely important in the study of mortars, because while the former determines the water retention capacity of the material, so that there is enough water for the cement hydration reactions, the latter can be considered as an indirect measure of mortar workability, because mortars with higher levels of incorporated air are more plastic. However, special care should be taken for mortars with high levels of incorporated air, as they may exhibit excessive porosities and future pathological problems (Mattana et al., 2012).

The properties evaluated in the hardened state were verified after 28 days of air curing, in an environment with temperature of $23 \pm 2{ }^{\circ} \mathrm{C}$. The following variables were evaluated: mass density in the hardened state using the NBR 13280 procedure (ABNT, 2005d), flexural strength and compressive strength through NBR 13279 (ABNT, 2005c), water absorption by immersion through NBR 9778 (ABNT, 2009), and water absorption by capillarity using NBR 15259 (ABNT, 2005e).
All tests used three prismatic test specimens with dimensions of $40 \times 40 \times 160 \mathrm{~mm}$, as determined by the Brazilian norms used in the study.

Mass density in the hardened state is obtained by dividing the mass of the samples after 28 days by the specimen volume, already predetermined. Strength tests for the rupture of the test specimens were conducted using an EMIC universal testing machine with S-shaped load cell with $30 \mathrm{kN}$ capacity, at loading rate of $50 \pm 10 \mathrm{~N} \mathrm{~s}^{-1}$ for bending and $500 \pm 10 \mathrm{~N} \mathrm{~s}^{-1}$ for compression. In the water absorption test, the specimens were dried in an oven after the curing period for $24 \mathrm{~h}$. The dry mass of the test specimens was then obtained. The specimens were immersed in distilled water for more $24 \mathrm{~h}$, which allowed obtaining their wet masses. Water absorption by immersion is determined by the relationship between the water absorbed by the mortars and the dry mass of the material, in percentage. Lastly, the capillarity test is performed by positioning the specimens with the square base on a porous stone, in contact with a 5 -mm-deep film of water. The water starts to rise in the test specimen by capillarity, increasing its weight. Therefore, the masses are measured after 10 and 90 min of test. The capillarity coefficient, calculated according to the Brazilian standard used, is obtained by subtracting the average mass at $90 \mathrm{~min}$ of test from the mass obtained at $10 \mathrm{~min}$ of test. Statistical treatment consisted of Tukey's test to compare the means at $\mathrm{p} \leq 0.05$.

\section{Results AND Discussion}

Statistical treatment consisted of Tukey's test to compare the means at $5 \%$ confidence level. The results obtained in the tests of consistency, water retention and incorporated air concentration are presented in Table 1 . The percentages of the fibers used in the study were tested with the same amount of water obtained for the reference percentage $(0 \%)$, in order to verify whether the incorporation of the fibers hampered or improved the workability of the cementitious matrix. Thus, the water/cement ratio used in this study was 1.50 .

By evaluating the results obtained in Table 1 for consistency index, it is possible to identify a reduction in the workability of the mortars with the incorporation of the fibers, although this decrease is not very pronounced (around 4\%). Mortars containing treated fibers showed greater workability than those with natural fibers, which can be attributed to the greater water absorption of natural fibers, which did not undergo $\mathrm{NaOH}$ treatment to become less hygroscopic (Prado \& Spinacé, 2019). In the fresh state, this affects the free water present in the mortar structure, which instead of

Table 1. Properties of the mortars in the fresh state

\begin{tabular}{|cccc}
\hline Mortar & $\begin{array}{c}\text { Consistency } \\
\text { index }(\mathbf{m m})\end{array}$ & $\begin{array}{c}\text { Water } \\
\text { retention (\%) }\end{array}$ & $\begin{array}{c}\text { Incorporated air } \\
\text { concentration (\%) }\end{array}$ \\
\hline Reference percentage (\%) & 265.00 & 92.49 & 9.28 \\
2.5\% Natural & 262.50 & 94.84 & 9.74 \\
\hline $5.0 \%$ Natural & 260.33 & 95.32 & 9.56 \\
7.5\% Natural & 258.67 & 96.22 & 9.33 \\
10.0\% Natural & 256.33 & 96.86 & 9.04 \\
\hline 2.5\% Treated & 263.33 & 92.65 & 9.22 \\
\hline $5.0 \%$ Treated & 261.00 & 92.98 & 9.16 \\
\hline $7.5 \%$ Treated & 259.00 & 93.02 & 9.10 \\
\hline $10.0 \%$ Treated & 257.33 & 93.71 & 8.96 \\
\hline
\end{tabular}


being free and contributing to the fluidity of the material, is impregnated in the natural fibers. Based on the workability value recommended by NBR 13276 (ABNT, 2016), in the range of $260 \pm 5 \mathrm{~mm}$, the incorporations of 7.5 and $10 \%$ of fibers, both natural and treated, despite meeting the normative requirements of workability, are less indicated compared to the reference percentage ( $0 \%)$ and the other compositions studied. Therefore, they are not recommended for this water/cement ratio, considering only this property.

On water retention, also illustrated in Table 1, it can be observed that mortars with natural fibers have higher retention, which can be attributed to the capacity of pineapple fibers to absorb the water present in the cementitious material. This information may lead to a false interpretation that the mortars with natural fibers are beneficial, but one should consider that the retained water is impregnated in the fibers and not in its free form, hence not contributing to cement hydration, as will be better discussed in the interpretation of the mechanical strength results. Mortars containing treated fibers have slightly higher water retention compared to the retention of the reference mortar, so it is possible to consider that treated fibers do not interfere in the water retention of mortars. This fact confirms the efficiency of the $\mathrm{NaOH}$ treatment, which made the fibers less hygroscopic. As will be verified in the results of mechanical strength, the retained water can be evaluated as free water, since the hydration of the cement in the mortars with treated fibers was not hampered, because these mortars showed increased strength. It should be pointed out that all percentages under study have high levels of water retention. Gomes \& Neves (2002) recommend that mortars have retention values higher than $75 \%$, and, therefore, following this criterion, all mortars exhibit a very satisfactory behavior.

Regarding the incorporated air concentration, it can be observed that mortars with natural fiber have higher concentrations than the reference ratio, a result that was not verified only for the percentage with $10 \%$ of natural fibers. This tendency accompanies the reduction in workability verified as the natural fibers are incorporated, and it is due to the fact that the fibers do not have good adhesion with the cementitious matrix, which ensures higher concentration of incorporated air most likely occurring precisely at the matrix-fiber interface. Mortars with treated fibers exhibit a gradual decrease in the air incorporated concentration as the fiber incorporation increases, and all of them have lower concentrations than the reference ratio. This fact corroborates the study conducted by Mattana et al. (2012), in which the authors concluded that there is an almost linear tendency between workability and incorporated air concentration, where mortars with lower concentrations also have lower levels of workability. The results obtained for treated fibers are consistent with the theory obtained in the study of these authors. On the other hand, it is worth pointing out that the fact that the incorporated air concentration of mortars with treated fibers is lower than those obtained in mortars with treated fibers corroborates what was presented by Motaleb et al. (2018). These authors highlighted the importance of $\mathrm{NaOH}$ treatments in pineapple fibers, which after treatment began to show higher adhesions with the matrix, which caused a reduction in the incorporated air concentrations for mortars with fibers treated in $\mathrm{NaOH}$ solution. On the reference values, Mattana et al. (2012) highlighted that mortars should have the incorporated air concentration limited to $20 \%$, while Gomes \& Neves (2002) suggest that the incorporated air concentration should be within the range between 8 and 17\%. Taking these values as reference, all mortars under study have good behavior with respect to the properties of air incorporated. Although the discussion presented is valid, the differences obtained in the results of incorporated air concentration and water retention are small and may have been caused by the process of mixing, molding or weighing.

Figure 2 shows the mass density results in the hardened state. It is possible to confirm that both incorporations, natural and treated fibers, reduce the mass density in the hardened state of mortars when compared to the reference percentage $(0 \%)$. This result had already been reported by other authors (Silva et al., 2014; Jaramillo et al., 2016) and is due to the lower density that the fibers have in comparison to the other materials used in the manufacture of mortars. The described fact is beneficial from the technological point of view since mortars with lower densities contribute less significantly to the weight loadings characteristic of buildings.

By comparing the effect of the fiber treatment on the density of mortars for laying and coating, it is verified that the treated fibers have higher reductions of density than natural fibers, which can be attributed to the impregnated water that remains present in the fibers when they are not properly treated (Motaleb et al., 2018). This impregnated water may cause future pathological problems in the systems constructed with these mortars, due to retractions and contractions of hygroscopic nature.

The results of flexural tensile strength are expressed by $y=0.062 x+2.645\left(R^{2}=0.2882\right)$ for treated fiber and $y=-0.008 x+2.01\left(R^{2}=0.0228\right)$ for natural fiber. It was not possible to obtain an adequate adjustment for this property. It can be observed that the incorporation of fibers in both evaluated forms improves the properties of flexural strength. This is due to the type of procedure used in this test, in which the prismatic specimens are subjected to a 3-point bending,

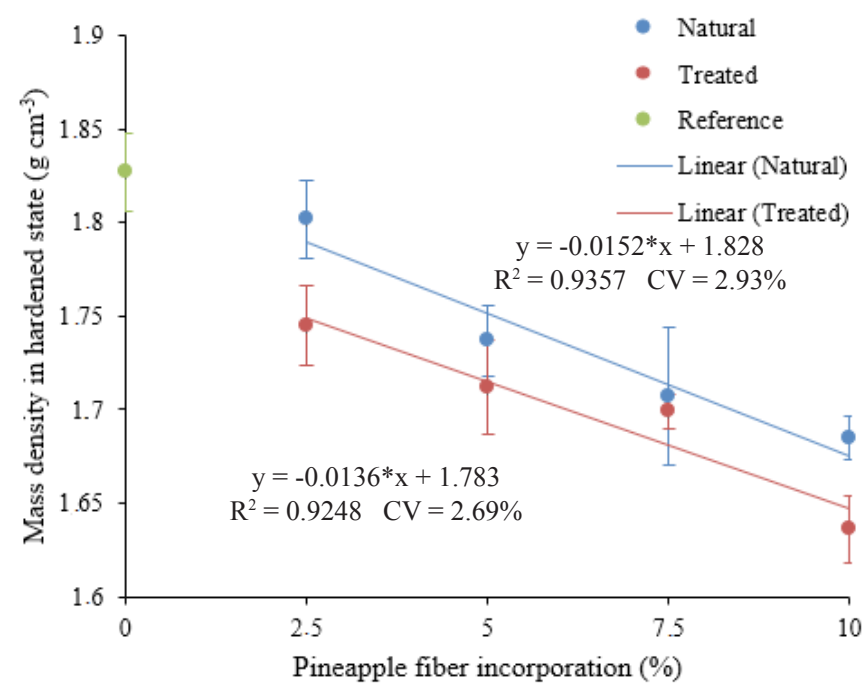

* Significant at $\mathrm{p} \leq 0.05$ by $\mathrm{F}$ test

Figure 2. Mass density in the hardened state for the mortars as function of pineapple fiber incorporation 
simulating loads that occur in beams, for instance, but on a reduced scale. In this type of test, the fibers act as structural reinforcement, in the same way that the steel bars work on the reinforced concrete. The effect of the fibers was also verified on the type of rupture observed, where the reference percentage (0\%) had an abrupt rupture because it is a fragile material (Marvila et al., 2019). The mortars containing pineapple fibers did not break in this way, demonstrating that the fibers act on the capacity of the studied mortar to absorb stresses. It is worth pointing out that the specimens of the mortar made with pineapple fibers did not separate after rupture, and the samples remained visibly intact, while the mortars of the reference percentage (0\%) separated into two parts after the test.

Also on this test, a fact of extreme importance should be highlighted: during the unmolding of the specimens, which occurred around 5 days after the molding of mortars, it was found that mortars with incorporation of natural fibers were still in a plastic state, exhibiting a softened appearance, while the reference mortar and the mortar with treated fibers had enough strength to be unmolded without difficulties. Silva et al. (2009) point out that this occurs due to the chemical incompatibility existing between the plant fibers and the cementitious matrix. This fact contributed to the decrease of strength observed in natural fibers compared to treated fibers and makes it impossible to use untreated fibers as incorporation in cementitious materials, since the sugar present in the impurities of the fiber acts as a very strong setting retardant (Motaeb et al., 2018), which inhibits the occurrence of cement hydration reactions and maintains the mortar in a semi-plastic state. Only with the treatment in $\mathrm{NaOH}$, which removes impurities and the sugar present in the pineapple crowns, it becomes feasible to incorporate fibers into cementitious matrices. Finally, it should be noted that the incorporation of $10 \%$ fiber is not recommended because it causes a reduction in the tensile strength of the mortars, compared to the ratio containing $7.5 \%$. Even in the mortar with natural fibers, it is observed that the incorporation of $10 \%$ of pineapple fiber only maintains the properties of strength. It is also known, as highlighted by Silva et al. (2009), that plant fibers in cementitious composites can undergo the action of different degradation agents, such as the water present in the material, $\mathrm{CO}_{2}$ from the atmosphere, cement hydration, which releases high alkalinity compounds, and the action of temperature and humidity. These degradation agents cause fiber decomposition or even petrification. Because of this, there is an optimum concentration of fiber incorporation, which in this study was $7.5 \%$ for flexural strength, from which fiber incorporation becomes harmful. Toledo Filho et al. (1997) had already found this result in their studies with coconut fibers, the same tendency verified by Silva et al. (2014). The authors attributed this fact to the usual procedures for mortar mixing, where the addition of a large volumetric fraction of fibers to the matrix introduces a greater number of defects resulting from inefficient compaction of the fresh mixture. These defects increase with the increment in the amount of fibers as the mixture becomes more rigid and less workable.

It is verified that the incorporation of natural fibers does not alter the properties of compressive strength of the mortars, i.e., statistically, it neither increases nor decreases the value of strength relative to the reference percentage $(0 \%)$, according to Tukey's test for comparison of means at $p \leq 0.05$. This result can be attributed to the lack of adhesion between cementitious matrix and fibers. Thus, the fibers act only as a filler, filling any empty spaces, which was also obtained by the reference mortar for other materials. As it does not reinforce the properties of compressive strength, it makes no sense to incorporate fibers in their natural form into a cementitious matrix. However, treated fibers significantly alter the compressive strength properties of the studied mortars. This demonstrates that the $\mathrm{NaOH}$ treatment is efficient in promoting greater roughness in the structure of the fibers and in promoting greater adhesion in the composite, which consequently has superior mechanical performance. In the compressive strength, there was also a reduction in the strength of the $10 \%$ percentage in comparison to the $7.5 \%$ percentage, evidencing the result obtained in flexural tensile strength. For comparison purposes, using the same reference percentage (0\%), Azevedo et al. (2018) obtained 1.26 MPa as flexural tensile strength and 3.10 $\mathrm{MPa}$ as compressive strength, whereas Marvila et al. (2019) obtained 1.41 MPa as flexural tensile strength and 4.38 $\mathrm{MPa}$ for compressive strength. This demonstrates that the values obtained were coherent.

Figure 3 presents the results of water absorption by immersion. This property is of great importance in the study on pineapple fiber incorporation because, as reported in the bibliography (Toledo Filho et al., 1999; Motaleb et al., 2018), plant fibers have high water absorption. This fact is evidenced in the analysis of the results of absorption of natural fibers, which showed significant increase in water absorption by immersion. For treated fibers, there was statistical equivalence up to the percentage of $5 \%$ incorporation. Mortars with 7.5 and $10 \%$ had higher incorporation than the reference percentage (0\%). This shows that the treatment with $\mathrm{NaOH}$, besides causing greater adhesion of the fiber to the matrix and reducing impurities,

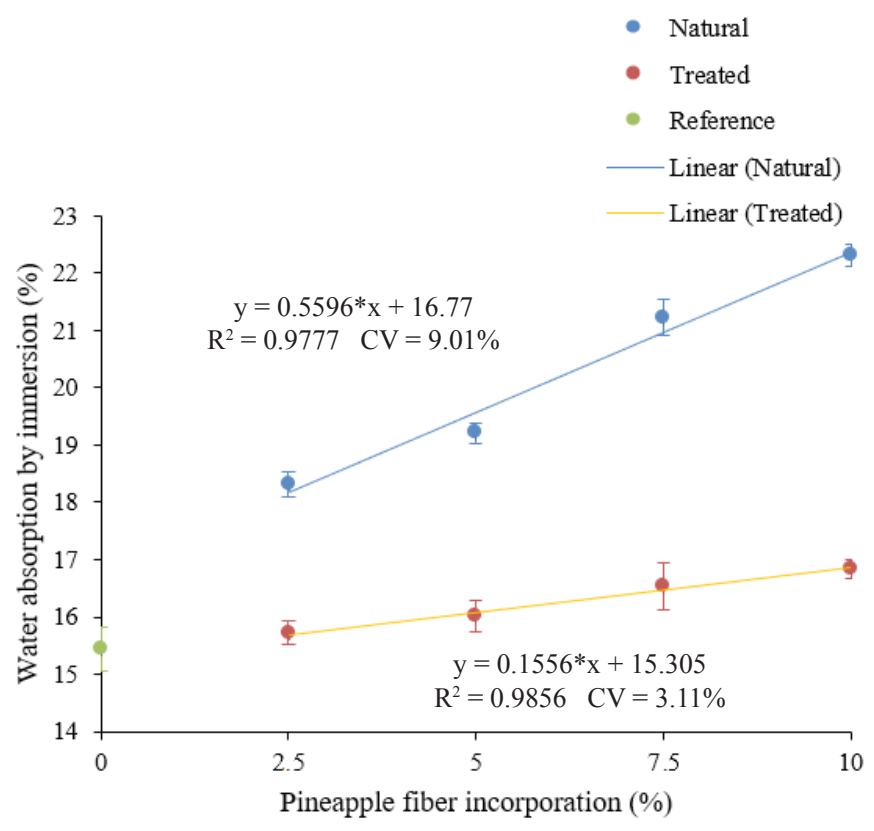

* Significant at $\mathrm{p} \leq 0.05$ by $\mathrm{F}$ test

Figure 3. Water absorption by immersion of the mortars as function of pineapple fiber incorporation 
such as sugar, which acts as a setting retardant in mortars, is efficient in reducing the water absorption by pineapple fibers. Because of this property, the use of mortars containing 7.5 or $10 \%$ of fiber incorporation, even if treated, is discouraged, since these percentages cause losses in the properties of water absorption by immersion. Studies such as that of Gomes \& Neves (2002), the authors suggest limiting the water absorption of mortars to values from 20 to $22 \%$, which would allow the incorporations of 7.5 and $10 \%$ of treated fibers. However, as mentioned above, in the present study it was decided to reject incorporations that cause losses in the studied properties, taking as reference percentage ( $0 \%$ incorporation).

Figure 4 presents the results of water absorption by capillarity. This phenomenon is one of the most complex to be evaluated and verified in mortars, as highlighted by Khatib et al. (2013) in their study on the effects of capillarity on concretes and other cementitious materials. According to these authors, the capillarity within cementitious materials is not solely related to the porosity of the material, but rather to what the authors called "active pores", which consist in a region of specific size in which the capillary phenomenon occurs. With this in mind, it is possible to understand the nonlinear behavior of the data obtained in the present study. In general, the data obtained for mortars with natural fibers increase almost linearly as the amount of incorporated pineapple fiber increases. The incorporations of 2.5 and $5 \%$ are equal to the reference $(0 \%)$. This evidences that, in order to maintain the same variables of the reference percentage (0\%), it is possible to use up to $5 \%$ of pineapple fibers in the studied materials. Moreover, it should be pointed out that, although the treated fibers do not affect the amount of active pores when used in smaller percentages, up to the limit of $5 \%$, it is very likely that there is an increase in the amount of active pores in the mortars containing large quantities of incorporation of these fibers, which demonstrates that there is an optimum concentration in the incorporation of $5 \%$ pineapple fibers.

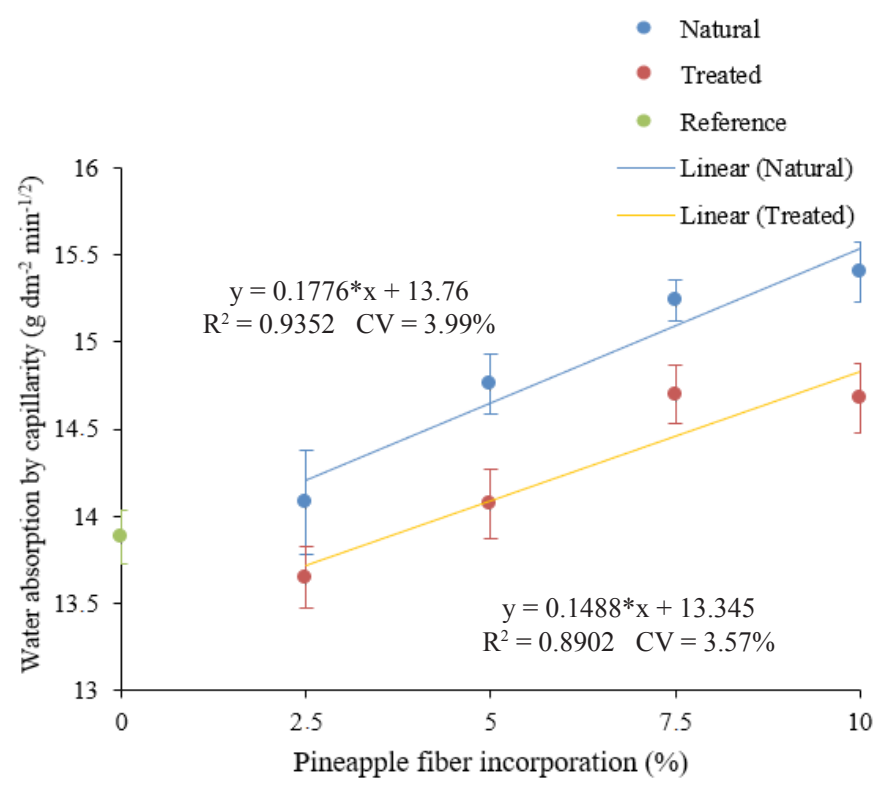

* Significant at $\mathrm{p} \leq 0.05$ by $\mathrm{F}$ test

Figure 4. Water absorption by capillarity of the mortars as function of pineapple fiber incorporation

\section{Conclusions}

1. The treatment with $\mathrm{NaOH}$ solution favored the reduction of water absorption by the fibers, favoring the hardening process of mortars for laying and coating due to the adhesion of the cementitious matrix with the reinforcement of natural fiber.

2. Incorporation of treated fibers up to $5 \%$ results in maintenance of workability properties in mortars with, gradual increase of water retention properties (from 92.49 to $92.98 \%$ ) and reduction in the concentration of the incorporated air (from 9.28 to $9.16 \%$ ).

3. Incorporation of fibers in natural state (without $\mathrm{NaOH}$ ) is not feasible, whereas the incorporation of pineapple crown fiber treated with $\mathrm{NaOH}$ solution up to $5.0 \%$ in relation to the cement mass is feasible from the technological point of view for the performance of the studied 1:1:6 mortars for laying and coating.

\section{Literature Cited}

ABNT - Associação Brasileira de Normas Técnicas. Argamassa para assentamento e revestimento de paredes e tetos - Determinação da retenção de água: NBR 13277. Rio de Janeiro: ABNT, 2005a. $3 p$

ABNT - Associação Brasileira de Normas Técnicas. Argamassa para assentamento e revestimento de paredes e tetos - Determinação da densidade de massa e do teor de ar incorporado: NBR 13278. Rio de Janeiro: ABNT, 2005b. 4p.

ABNT - Associação Brasileira de Normas Técnicas. Argamassa para assentamento e revestimento de paredes e tetos - Determinação da resistência à tração na flexão e à compressão: NBR 13279. Rio de Janeiro: ABNT, 2005c. 9p.

ABNT - Associação Brasileira de Normas Técnicas. Argamassa para assentamento e revestimento de paredes e tetos - Determinação da densidade de massa aparente no estado endurecido: NBR 13280. Rio de Janeiro: ABNT, 2005d. 2p.

ABNT - Associação Brasileira de Normas Técnicas. Argamassa para assentamento e revestimento de paredes e tetos - Determinação da absorção de água por capilaridade e do coeficiente de capilaridade: NBR 15259. Rio de Janeiro: ABNT, 2005e. 3p.

ABNT - Associação Brasileira de Normas Técnicas. Argamassa e concretos endurecidos - Determinação da absorção de água, índice de vazios e massa específica: NBR 9778. Rio de Janeiro: ABNT, 2009. 4p.

ABNT - Associação Brasileira de Normas Técnicas. Argamassa para assentamento e revestimento de paredes e tetos - Preparo da mistura e determinação do índice de consistência: NBR 13276. Rio de Janeiro: ABNT, 2016. 2p.

Azevedo, A. R. G.; Alexandre, J.; Xavier, G. C.; Pedroti, L. G. Recycling paper industry effluent sludge for use in mortars: A sustainability perspective. Journal of Cleaner Production, v.192, p.335-346, 2018. https://doi.org/10.1016/j.jclepro.2018.05.011

Barros, R. G. C.; Andrade, J. K. S.; Denadai, M.; Nunes, M. L.; Narain, $\mathrm{N}$. Evaluation of bioactive compounds potential and antioxidant activity in some Brazilian exotic fruit residues. Food Research International, v.102, p.84-92, 2017. https://doi.org/10.1016/j. foodres.2017.09.082 
Bencha, B.; Azzouz, L.; Kadri, E. H.; Kenai, S.; Belaidi, A. S. E. Effect of fine aggregates replacement with desert dune sand on fresh properties and strength of self-compacting mortar. Journal of Adhesion Science and Technology, v.28, p.2182-2195, 2014. https://doi.org/10.1080/01694243.2014.950625

Gil, L. S.; Maupoey, P. F. An integrated approach for pineapple waste valorization. Bioethanol production and bromelain extraction from pineapple residues. Journal of Cleaner Production, v.172, p.1224-1231, 2018. https://doi.org/10.1016/j.jclepro.2017.10.284

Gomes, A. O.; Neves, C. M. M. Proposta de método de dosagem racional de argamassas contendo argilominerais. Ambiente Construído, v.2, p.19-30, 2002.

Hazarika, D.; Gogoi, N.; José, S.; Das, R.; Basu, G. Exploration of future prospects of Indian pineapple leaf, an agro waste for textile application. Journal of Cleaner Production, v.141, p.580-586, 2017. https://doi.org/10.1016/j.jclepro.2016.09.092

IBGE - Instituto Brasileiro de Geografia e Estatística. Pesquisa da produção brasileira de abacaxi em 2017. Rio de janeiro, 2018.

Jaramillo, N.; Hoyos, D.; Santa, J. F. Composites with pineapple-leaf fibers manufactured by layered compression molding. Ingeniería y Competitividad, v.18, p.151-162, 2016. https://doi.org/10.25100/ iyc.v18i2.2163

Khatib, J. M.; Herki, B. A.; Kenai, S. Capillarity of concrete incorporating waste foundry sand. Construction and Building Materials, v.47, p.867-871, 2013. https://doi.org/10.1016/j. conbuildmat.2013.05.013

Lima, P. C. C.; Souza, B. S.; Santini, A. T.; Oliveira, D. C. Aproveitamento agroindustrial de resíduos provenientes do abacaxi 'Pérola' minimamente processado. Holos, v,2, p.122-136, 2017. https://doi.org/10.15628/holos.2017.5238

Manetti, L. M. Metabólitos secundários da família bromeliaceae. Química Nova, v.15, p.1-13, 2009. https://doi.org/10.1590/S010040422009000700035

Martinelli, G. C.; Schlindwein, M. M.; Padovan, M. P.; Gimenes, R. M. T. Decreasing uncertainties and reversing paradigms on the economic performance of agroforestry systems in Brazil. Land Use Policy, v.80, p.274-286, 2019. https://doi.org/10.1016/j. landusepol.2018.09.019

Marvila, M. T.; Alexandre, J.; Azevedo, A. R. G.; Zanelato, E. B.; Evaluation of the use of marble waste in hydrated lime cement mortar based. Journal of Material Cycles and Waste Management, p.1-13, 2019. https://doi.org/10.1007/s10163-019-00878-6
Mattana, A. J.; Medeiros, M. H. F.; Silva, N. G.; Costa, M. R. M. M. Análise hierárquica para escolha entre agregado natural e areia de britagem de rocha para confecção de argamassas de revestimento. Ambiente Construído, v.12, p.63-79, 2012. https:// doi.org/10.1590/S1678-86212012000400006

Motaleb, K. Z. M.; Shariful, M. I.; Hoque, M. B. Improvement of physicomechanical properties of pineapple leaf fiber reinforced composite. International Journal of Biomaterials, v.10, p.1-7, 2018. https://doi.org/10.1155/2018/7384360

Prado, K. S.; Spinacé, M. A. S. Isolation and characterization of cellulose nanocrystals from pineapple crown waste and their potential uses. International Journal of Biological Macromolecules, v.122, p.410416, 2019. https://doi.org/10.1016/j.ijbiomac.2018.10.187

Reddy, M. I.; Varma, P. U. R.; Kumar, I. A.; Manikanth, V.; Raju, P. V. K. Comparative evaluation on mechanical properties of jute, pineapple leaf fiber and glass fiber reinforced composites with polyester and epoxy resin matrices. Materials Today, v.5, p.56495654, 2018. https://doi.org/10.1016/j.matpr.2017.12.158

Rojas, L. F.; Cortés, C. F.; Zapata, P.; Jiménez, C. Extraction and identification of endopeptidases in convection dried papaya and pineapple residues: A methodological approach for application to higher scale. Waste Management, v.78, p.58-68, 2018. https:// doi.org/10.1016/j.wasman.2018.05.020

Silva, A. C. e; Salvastano Junior, H.; John, V. M. Envelhecimento de compósitos à base de escória de alto-forno reforçados com polpa celulósica residual de eucalipto. Ambiente Construído, v. 9, n. 1, p. 25-44, 2009.

Silva, E. J.; Silva, P. D.; Marques, M. L.; Fornari Junior, C. C. M.; Garcia, F. J.; Luzardo, F. H. M. Resistência à compressão de argamassas em função da adição de fibra de coco. Revista Brasileira de Engenharia Agrícola e Ambiental, v.18, p.1268-1273, 2014. https:// doi.org/10.1590/1807-1929/agriambi.v18n12p1268-1273

Toledo Filho, R. D.; England, G. L.; Ghavami, K. Comportamento em compressão de argamassas reforçadas com fibras naturais. Revista Brasileira de Engenharia Agrícola Ambiental, v.1, p.79-88, 1997. https://doi.org/10.1590/1807-1929/agriambi.v1n1p79-88

Toledo Filho, R. D.; Joseph, K.; Ghavami, K.; England, G. L. The use of sisal fiber as reinforcement in cement based composites. Revista Brasileira de Engenharia Agrícola Ambiental, v.3, p.245-256, 1999. https://doi.org/10.1590/1807-1929/agriambi.v3n2p245-256

Yusri, Y.; Yahya, S. A.; Adam, A. Novel technology for sustainable pineapple leaf fibers productions. Procedia CIRP, v.26, p.756-760, 2015. https://doi.org/10.1016/j.procir.2014.07.160 